\title{
The Influence of Pt Atomic Ratio in the Activity PtNi/C Nanocatalysts for the PEMFC
}

\author{
Nenen Rusnaeni ${ }^{1}$, Widodo Purwanto W. ${ }^{1}$, Mohammad Nasikin ${ }^{1}$ \& \\ Lilik Hendrajaya ${ }^{2}$ \\ ${ }^{1}$ Department of Chemical Engineering, Faculty of Engineering, \\ University of Indonesia \\ ${ }^{2}$ Institute of Technology Bandung \\ Email: mnasikin@che.ui.ac.id
}

\begin{abstract}
Pt-Ni/C alloy nanocatalysts synthesized by polyol method with different atomic ratio are investigated to enhance activity of the oxygen reduction reaction (ORR) for fuel cell applications. Prepared catalysts are characterized by various techniques, such as X-ray diffraction (XRD), scanning electron microscopy (SEM-EDX), and cyclic voltammetry (CV). XRD analysis shows that all prepared catalysts with different atomic ratio exhibit face centered cubic and have smaller lattice parameters than pure Pt catalyst. The mean particle size of the catalysts are between 4.3 to $6.3 \mathrm{~nm}$. Cyclic voltammograms with scan rate $5 \mathrm{mV} \mathrm{s}-1$ at $25^{\circ} \mathrm{C}$ obtain range the electrochemical active surface (EAS) between 40 to $164 \mathrm{~cm} 2 / \mathrm{mgPt}$, mass activity (MA) and specific activity (SA) of nanocatalysts $\mathrm{PtNi} / \mathrm{C}$ in the potential range $900 \mathrm{mV}$ versus $\mathrm{RHE}$ between 3.61 to $8.42 \mathrm{~mA} / \mathrm{mgPt}$, and 0.05 to 0.09 .
\end{abstract}

Keywords: alloy nanocatalyst; fuel cell; PtNi; oxygen reduction reaction (ORR).

\section{$1 \quad$ Introduction}

Fuel cells are becoming a subject of intense applied research for portable, stationary, and electric vehicle applications due to their highly efficient conversion, high power density and low pollution. Among the various types of fuel cell, the proton exchange membrane fuel cell (PEMFC) is an attractive power source and the most suitable candidate for electric vehicle and residential application. PEMFC can be operated at a low temperature of $<100^{\circ} \mathrm{C}$. Each hydrogen atom is split into a proton and an electron with the aid of a catalyst.

The electrons must go around the membrane through a circuit, doing work along the way. Finally, the protons that pass through an electrolyte membrane and electrons recombine with oxygen to form water and heat.

Carbon supported platinum $(\mathrm{Pt} / \mathrm{C})$ is widely used as the commercial electrocatalyst in PEMFC. However, since platinum is expensive and the

\footnotetext{
* Part of the results was presented in the 11th Int. Conf. on QIR: Nano Material for Energy at University of Indonesia, Depok.

Received October $22^{\text {nd }}, 2010$, Revised November $29^{\text {th }}, 2010$, Accepted for publication November $30^{\text {th }}, 2010$.
} 
world's supply of Pt is limited there is a need to promote alternatives to reduce the use of Pt.

Therefore, how to improve the electrocatalytic activity is a very important issue [1-3].The search for oxygen reduction reaction (ORR) catalysts that are more active, less expensive and with greater stability than Pt has resulted in the development of Pt-based transition metal alloys [4,5]. Some platinum-based binary alloys have the best prospect to be used as a cathode catalyst such as $\mathrm{PtCr}, \mathrm{PtZr}, \mathrm{PtTi}$, that exhibit a higher catalytic activity for ORR in acid electrolytes than pure platinum [3]. However to improve the performance of the Pt-based metal alloys, it is necessary to taylor the electrocatalyst layer to achieve the optimum membrane electrode assembly water balance under the selected PEMFC operating conditions. Such alloy catalysts could improve the activity against oxygen reduction by a direct four-electrons reaction without involving the intermediate hydrogen peroxide step. The mechanisms for the enhanced activity of platinum alloy catalysts againts oxygen reduction have been studied extensively in recent years [4]. Mukerjee S. [5] has explained the improvement in the PtCo catalytic activity based on an increase in the d-orbital vacancy promoting a stronger metal-oxygen interaction, particle size, and the inhibition of formation of Pt-OH at potentials above $800 \mathrm{mV}$ vs RHE [5]. A stronger Pt- $\mathrm{O}_{2}$ bond can cause a weakening and lengthening of the $\mathrm{O}-\mathrm{O}$ bond and an easier scission of the $\mathrm{O}-\mathrm{O}$ bond, resulting in an increase in the reaction rate. On the other side, an increase in the d-band vacancy in Pt makes it difficult to free an electron for oxygen reduction. The enhanced electrocatalytic activity of the $\mathrm{PtCr}, \mathrm{PtCo}, \mathrm{PtCu}$ and $\mathrm{PtNi}$ can be explained by an electronic factor, i.e. the change of the d-band vacancy in Pt upon alloying and/or by geometric effects ( $\mathrm{Pt}$ coordination number and based on the decrease in the PtPt distance) [6]. In the present research, nickel (Ni) transition metal was used. This transition metal has received little attention in synthesizing the $\mathrm{Pt}$ alloying catalyst, although $\mathrm{Ni}$ has almost similar atomic radius to $\mathrm{Co}$ and $\mathrm{Fe}$. Ni had been studied before in anode PEMFC, but the more critical issue is a study of $\mathrm{Ni}$ in improving ORR activity, which has not been fully analyzed.

In this research $\mathrm{PtNi} / \mathrm{XC}-72 \mathrm{R}$ was prepared and characterized by various techniques. XRD characterization was carried out to determine the crystalline stucture, the mean crystalline size and the lattice parameter of these prepared $\mathrm{PtNi} / \mathrm{C}$ nanocatalysts. EDX result was used to investigate the bulk composition. $\mathrm{CV}$ tests are also conducted to determine EAS, MA, and SA as the ORR activity. 


\section{$2 \quad$ Materials and Methods}

\subsection{Preparation}

The carbon supported PtNi catalysts are prepared by the ethylene glycol method. $\mathrm{H}_{2} \mathrm{PtCl}_{6}$ and transition metal $\mathrm{NiCl}_{2} .6 \mathrm{H}_{2} \mathrm{O}$ precursor solution is mixed well and added to carbon ethylene glycol solution, under mechanically stirred conditions. $2.5 \mathrm{M} \mathrm{NaOH}$ is added to adjust the $\mathrm{pH}$ of the solution to about 10 . The temperature is then refluxed at $190^{\circ} \mathrm{C}$ for 2 hours. The system was cooled to room temperature, the obtained products were washed with distilled water, and was filtered under vacuum. Finally, the solid residu was dried to yield $\mathrm{PtNi} / \mathrm{C}$ powder.

The used materials in the experimental work were: hexachloroplatinic acid $\left(\mathrm{H}_{2} \mathrm{PtCl}_{6}\right)$ from Aldrich, nickel chloride $\left(\mathrm{NiCl}_{2} \cdot 6 \mathrm{H}_{2} \mathrm{O}\right)$ from Merck, and activated carbon VulcanX72R from Cabot, sodium hydroxide $(\mathrm{NaOH})$ from Merck and ethylene glycol (EG) aqueous solution from Merck. For reference, the $\mathrm{Pt} / \mathrm{C}$ commercial electrocatalyst used was from E-TEK's product. $\mathrm{PtNi} / \mathrm{C}$ alloy has metal loading of $30 \mathrm{wt} \%$ and atomic ratio variations were follows: $\mathrm{Pt}: \mathrm{Ni}=1: 1$ as PtNi11 sample; 3:1 as PtNi31 sample; 4:1 as PtNi41 sample.

\subsection{Characterization}

All prepared catalysts are characterized by powder XRD pattern on an X-ray diffractometer using $\mathrm{CuK} \alpha$ radiation with a Ni filter and step scanning. The tube current is $30 \mathrm{~mA}$ and tube voltage is $40 \mathrm{kV}$. The diffraction angles $2 \Theta$ (2 theta) were selected from $35^{\circ}$ to $80^{\circ}$. The Pt diffraction peaks are used to calculate the mean size of the Pt particles according to Scherrer's formula:

$$
D=0.9 \lambda_{\mathrm{K \alpha} 1} / B_{2 \theta} \cos \theta
$$

$D$ is mean size of Pt particles, $\lambda$ is the $\mathrm{X}$-ray wavelengh, $B$ is the half-peak width for the peak in radians, $\theta$ is the maximum angle of the peak. The accuracy of this method is around $5 \mathrm{~nm}$.

The metal composition of these PtNi/C catalysts is determined by EDX and The position of $\mathrm{Pt}$ atom is exposed by SEM mapping. The $\mathrm{CV}$ measurement uses an $\mathrm{Ag} / \mathrm{AgCl}$ electrode as the reference electrode and a platinum wire for the counter electrode. It was performed using Potensiostat eDAQ instrumentation. The nanocatalyst layer of the working electrode is prepared as follows : a mixture containing $\mathrm{PtNi} / \mathrm{C}$ catalysts, ethanol and $5 \mathrm{wt} \%$ Nafion are ultrasonically blended in a glass vessel for half an hour to obtain a homogeneous ink. The ink is brushed onto the surface of carbon electrode and dried in an oven at $80^{\circ} \mathrm{C}$ for 10 minute to obtain a thin active catalytic layer. The electrolyte is $1 \mathrm{M} \mathrm{HClO}_{4}$ solution (which is a weak anion adsorption acid 
and can be used to evaluate the mass activity well). CV is obtained after using high purity nitrogen to clean the electrolyte solution for $20 \mathrm{~min}$. The scan rate is $50 \mathrm{mV} / \mathrm{s}$ and scan range is from -0.2 to $1.2 \mathrm{~V}(\mathrm{Ag} / \mathrm{AgCl})$. The ORR tests are started after the oxygen bubbling for $20 \mathrm{~min}$. The ORR tests can be used to evaluate the catalytic activity i.e. mass activity (MA) and specific activity (SA).

\section{$3 \quad$ Results and Discussion}

The metal bulk compositions of these $\mathrm{PtNi} / \mathrm{C}$ catalysts determined by EDX are shown in Table 1. From this table, PtNi31 sample is found to have higher Pt loading than PtNi11 and PtNi41 sample. The Pt loading of all samples are lower than the setting value. The nanocatalysts are strongly related to the alloy composition on the surface. The properties will be different from those of the bulk.

Table 1 Metal composition, lattice parameters, and particle size of Pt-Ni/C.

\begin{tabular}{|c|c|c|c|c|}
\hline \multirow[t]{2}{*}{ Sample } & $\begin{array}{c}\text { C: Metal } \\
\text { wt\% }\end{array}$ & $\begin{array}{l}\text { Pt:Ni } \\
\text { wt } \%\end{array}$ & $\begin{array}{c}\text { Lattice } \\
\text { Parameters }\end{array}$ & $\begin{array}{l}\text { Particle } \\
\text { Size }\end{array}$ \\
\hline & \multicolumn{2}{|c|}{$\left({ }^{\circ} \mathbf{A}\right)$} & \multicolumn{2}{|l|}{$(\mathbf{n m})$} \\
\hline PtNi11 & $71: 29$ & $23: 77$ & 3.64 & 5.7 \\
\hline PtNi31 & 80:20 & $37: 63$ & 3.66 & 6.3 \\
\hline PtNi41 & $49: 51$ & 29:71 & 3.81 & 4.3 \\
\hline $\begin{array}{l}\text { Pt/C E-TEK } \\
\text { Commercial }\end{array}$ & 70:30 & - & 3.93 & 5.9 \\
\hline
\end{tabular}

Figure 1 compares the X-ray diffraction patterns of the $\mathrm{Pt} / \mathrm{C}$ and $\mathrm{PtNi} / \mathrm{C}$ catalysts. The diffraction peaks of the PtNi/C alloy catalysts shift to higher angles as compared to that of $\mathrm{Pt} / \mathrm{C}$, indicating a lattice contraction arising from the substitution of the smaller Ni atoms for the larger Pt atoms. All the XRD peaks can be indexed as face-centered cubic (fcc) structure [7,8]. The lattice parameters and the mean $\mathrm{PtNi} / \mathrm{C}$ particle sizes were calculated with Scherrer's formula based on $\operatorname{Pt}(111)$ peak and listed in Table 1.

With the data given in Table 1, the lattice parameter and hence the average Pt$\mathrm{Pt}$ distance is decreased as the ratio of atomic Pt increased. The PtNi system of PtNi11, PtNi31 and PtNi41 samples under this composition exhibit a single phase with the $\mathrm{PtNi}_{3}$ type structures as evident in the phase diagram [9]. The $\mathrm{PtNi}_{3}$ has a cubic structure in which the $\mathrm{Pt}$ atoms occupy corner positions and the $\mathrm{Ni}$ atoms occupy the face-centered positions [10,11,12]. Because the shoulder of around $2 \Theta=70^{\circ}$ does not appear in the XRD results, it is determined that the PtNi has a disordered phase of face-centered cubic structure 
in which the $\mathrm{Pt}$ and $\mathrm{Ni}$ atoms are randomly distributed at the corner and facecentered positions. Figure 2 compares the voltammetric behavior of PtNi11, PtNi31, PtNi41 and Pt/C E-TEK commercial sample. From hydrogen desorption peak areas in the $\mathrm{CV}$ curve, and the $\mathrm{Pt}$ single crystalline activity surface area transition constant $\mathrm{Q}_{\mathrm{m}}=0.21 \mathrm{mC} / \mathrm{cm}^{2} \mathrm{Pt}$, the electrochemical active surface (EAS) for these catalysts is calculated, of which the results are shown in Table 2 and 3.

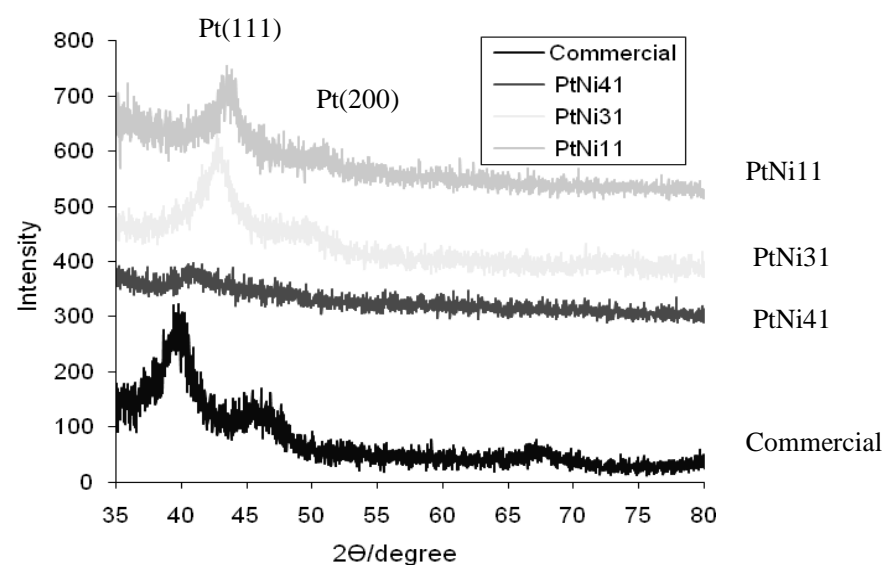

Figure 1 XRD patterns of Pt/C and PtNi/C prepared by EG method.

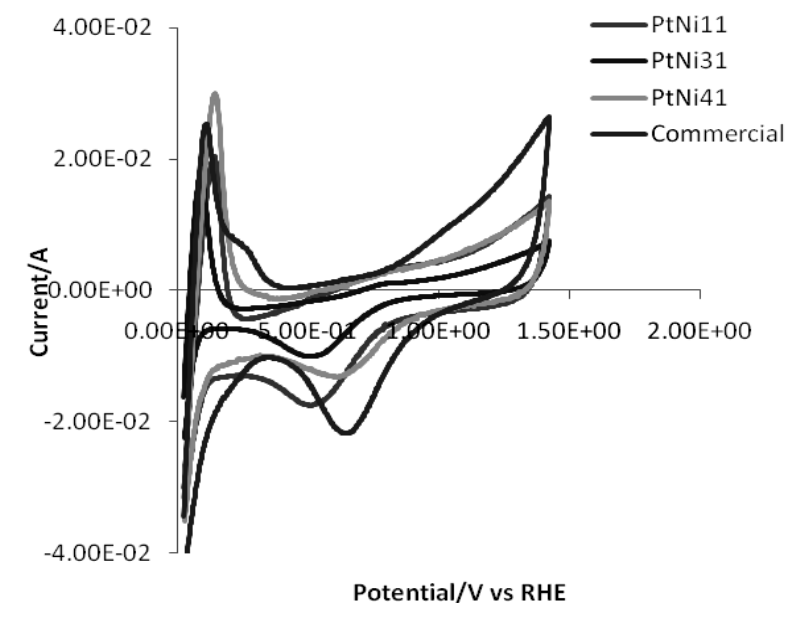

Figure 2 Cyclic voltammograms for $\mathrm{Pt} / \mathrm{C}$ commercial and $\mathrm{PtNi} / \mathrm{C}$ in $1 \mathrm{M}$ $\mathrm{HClO}_{4}$, saturated $\mathrm{N}_{2}$, the potential scan is $50 \mathrm{mV} / \mathrm{s}$. 
Table $2 \mathrm{H}_{2}$ Desorption and EAS for Pt/C and PtNi catalysts, scan speed 50 $\mathrm{mV} / \mathrm{s}$.

\begin{tabular}{ccc}
\hline Sample & $\begin{array}{c}\mathrm{H}_{2} \\
\text { Desorption } \\
(\mathrm{QH}) \mathrm{mC}\end{array}$ & $\begin{array}{c}\text { Electrochemical } \\
\text { Surface Area } \\
(\mathrm{EAS})(\mathrm{cm} 2 / \mathrm{mg})\end{array}$ \\
\hline PtNi11 & 2.38 & 36.56 \\
PtNi31 & 1.78 & 135.71 \\
PtNi41 & 4.1 & 155.95 \\
Pt/C E-TEK & 7.4 & 160.54 \\
Commercial & & \\
\hline
\end{tabular}

$\mathrm{Pt} / \mathrm{C}$ commercial has the largest electrochemical surface area (EAS), followed by PtNi11 and PtNi31. When the transition metal is added, the surface area becomes smaller. It can be seen that the platinum in the surface is replaced by nickel. The cyclic voltammograms results were evaluated by SEM mapping characterization.
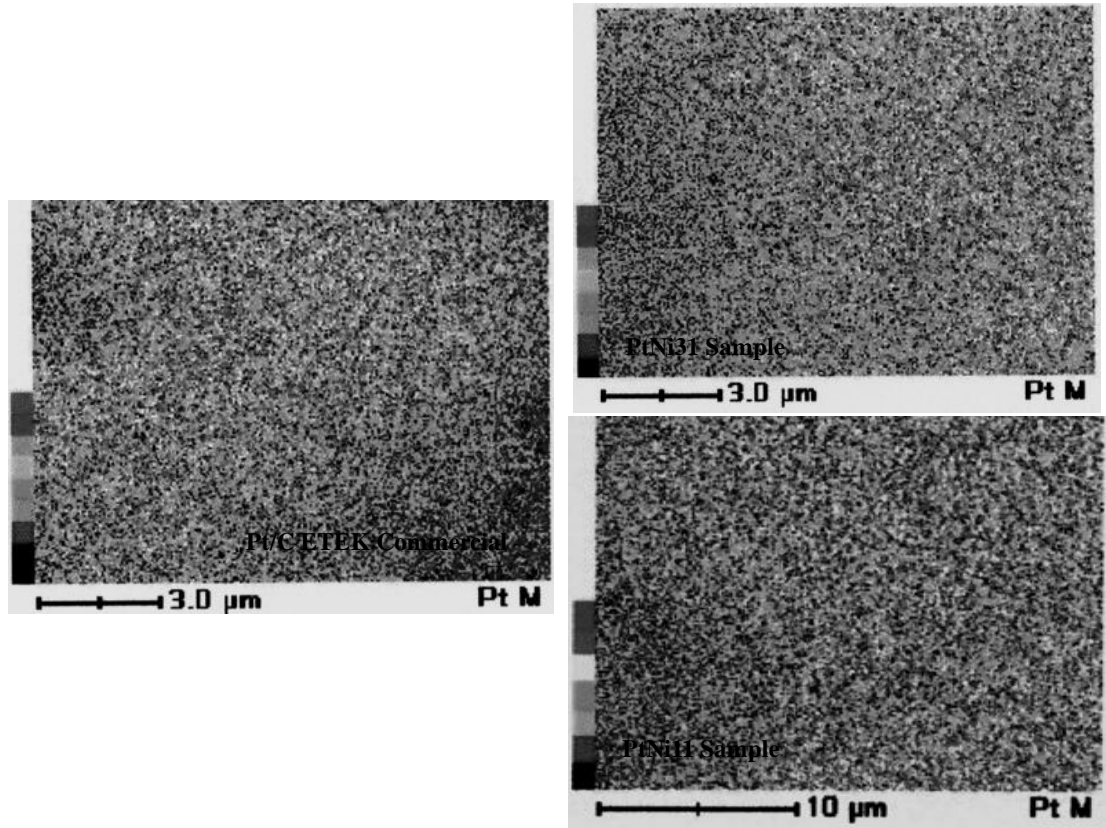

Figure 3 SEM Mapping of PtNi11, PtNi31, and Pt/C ETEK Commercial samples. 
Figure 3 shows SEM mapping image of the Pt particle distribution of PtNi31, $\mathrm{PtNi11}$, and $\mathrm{Pt} / \mathrm{C}$ commercial samples. The detected element qualitatively is platinum $(\mathrm{Pt})$. The map is a result of the sweeping of the backscattered electrons (BE) signal with specific energy. The lighter color shows the Pt particle at surface position. Pt/C commercial has the most exposed $\mathrm{Pt}$ atoms than PtNi31 and PtNi11. It was found that the exposed Pt atoms on PtNi/C have the good distribution. The influence of the Pt ratio on the exposed $\mathrm{Pt}$ atoms affects the catalytic activity.

Table 3 Electrochemical Activity for $\mathrm{Pt} / \mathrm{C}$ and $\mathrm{PtNi}$ catalysts, scan speed $5 \mathrm{mV} / \mathrm{s}$.

\begin{tabular}{|c|c|c|c|}
\hline \multirow[b]{2}{*}{ Sample } & \multicolumn{3}{|c|}{ At $900 \mathrm{mV}$ vs RHE } \\
\hline & $\begin{array}{l}\text { I0,9V } \\
(\mathrm{mA})\end{array}$ & $\begin{array}{c}\text { Mass } \\
\text { Activity (MA) } \\
(\mathbf{m A} / \mathbf{m g P t})\end{array}$ & $\begin{array}{c}\text { Specific } \\
\text { Activity (SA) } \\
(\mathbf{m A} / \mathbf{c m} 2)\end{array}$ \\
\hline PtNil1 & 1.01 & 3.61 & 0.099 \\
\hline PtNi31 & 0.47 & 6.71 & 0.049 \\
\hline PtNi41 & 1.01 & 8.42 & 0.054 \\
\hline $\begin{array}{l}\text { Pt/C E-TEK } \\
\text { Commercial }\end{array}$ & 1.05 & 4.77 & 0.03 \\
\hline
\end{tabular}

The ORR tests can be used to evaluate the catalytic activity [13]; there are generally two ways to express the catalytic activity : first is mass activity (MA), and the second is specific activity (SA). MA is the current per unit amount of catalyst and MA has practical implications in fuel cells because the cost of the electrode is largely dependent on the amount of platinum used. SA is the current per unit surface area of catalyst and the specific activity provides a measure of the electrocatalytic activity of platinum atoms in the particle surface. The MA and SA can be obtained through the following equations:

$$
\begin{aligned}
& \mathrm{MA}(\mathrm{mA} / \mathrm{mg})=\mathrm{i}_{0.9 \mathrm{v}} / \mathrm{W}, \\
& \mathrm{SA}\left(\mathrm{mA} / \mathrm{cm}^{2}\right)=\mathrm{i}_{0.9 \mathrm{v}} / \mathrm{EAS},
\end{aligned}
$$

where: W is the mass of Pt calculated

EAS is the electrochemical surface area.

The ORR test results of the catalysts are shown in Figure 4. The ORR current is negative, the absolute values of ORR for these catalysts are used. The ORR current of all sample is smaller than that of $\mathrm{Pt} / \mathrm{C}$ commercial, even though the reaction potential for the PtNi11 and PtNi41 samples is lower by $0.03 \mathrm{~V}$ than 
that of $\mathrm{Pt} / \mathrm{C}$. The reaction potential for PtNi31 sample is lower by $0.12 \mathrm{~V}$ than that of $\mathrm{Pt} / \mathrm{C}$. The activity results are shown in Table 3. Since the main concern is with the effects of formation Pt-OH, the attention will be focused on the region where the potential exceeds $0.9 \mathrm{~V}$ vs RHE [5]. In Figure 4 and Table 3, it is found that PtNi41 Sample has the highest MA of $8.42 \mathrm{~mA} / \mathrm{mg}$ and the highest EAS of $164.16 \mathrm{~cm}^{2} / \mathrm{mg}$, but PtNi11 sample has the highest SA of $0.09 \mathrm{~mA} / \mathrm{cm}^{2}$.

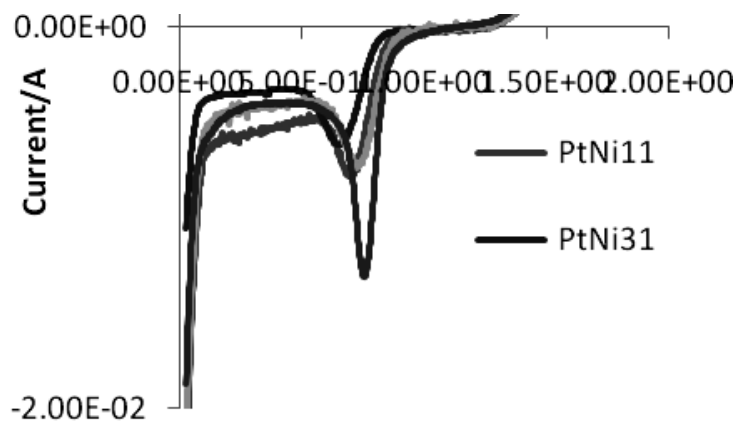

Potential/V vs RHE

Figure 4 The polarization curves for ORR on Pt/C commercial and Pt-Ni in $1 \mathrm{M}$ $\mathrm{HClO}_{4}$, The potential scan is $5 \mathrm{mV} / \mathrm{s}$.

Moreover PtNi/C shows a higher ORR activity than that of Pt/C E-TEK commercial. This may be attributed to the adition of $\mathrm{Ni}$ to Pt/C catalyst. The more electropositive $\mathrm{Ni}$ transition metal, to which the oxygen species is attached, provides an electrochemical force that favors the four electron oxygen reduction electrochemical pathways, and consequently improves the ORR activity of the catalyst [6]. This phenomenon is results of the adsorption property of oxygen on Pt surface by dual site mode. The addition of Ni to Pt/C catalyst not only reduces the Pt lattice parameter (the Pt-Pt nearest-neighbor distance plays an important role in determining the adsorption behavior), but also enhances the catalytic activity. Therefore the alloying effect is an important factor affecting the catalitic activity towards ORR.

\section{Conclusions}

In this study, the $\mathrm{Ni}$ transition metal was used to synthesize Pt alloy nanocatalysts. XRD and EDX characterizations are carried out to determine the structure of crystalline fcc and the Pt element composition that predicts a nanocatalysts surface of the single phase of $\mathrm{PtNi}_{3}$ type structure. The mean crystalline size of these $\mathrm{PtNi} / \mathrm{C}$ nanocatalysts ranges from 4.3 to $6.3 \mathrm{~nm}$. The replacement platinum indicate a lattice contraction arising from the substitution 
of the smaller $\mathrm{Ni}$ atoms for the larger Pt atoms. Electrochemical experiments cyclic voltammetry (CV) is also conducted to obtain the range of the electrochemical active area of alloy Pt nanocatalysts between 40 to $164 \mathrm{~cm}^{2} / \mathrm{mg}$. Cyclic voltammograms with scan rate $5 \mathrm{mV} \mathrm{s}^{-1}$ at $25^{\circ} \mathrm{C}$ determines $\mathrm{MA}$ in the potential range $900 \mathrm{mV}$ versus RHE with the result between 3.61 and 8.42 $\mathrm{mA} / \mathrm{mgPt}$, while SA is between 0.05 and 0.09. PtNi11, PtNi31, and PtNi41 Samples produced by polyol method have a more competitively mean size particle, EAS, MA, and with more SA values than that of $\mathrm{Pt} / \mathrm{C}$ commercial.

\section{Acknowledgements}

The financial support of The State Ministry of Research and Technology is gratefully acknowledged. The authors would like to thank The Department of Chemistry of the Faculty of Mathematics and Natural Sciences of The University of Indonesia for the utilization of cyclic voltametric apparatus, and The Department of Metallurgy of The Faculty of Engineering of The University of Indonesia for EDX characterization. The Support to attend a doctoral program and Assistance rendered by Research Center For Physics, Indonesian Institute of Sciences also highly appreciated.

\section{References}

[1] Tsou, Y.M., Zawodzinski, T., Mukerjee, S., Roelofs, M., Litt, M. \& Kalkhoran, N., Progress Report FY Departement of Energy, Hydrogen Programme, USA, 2006.

[2] Huerta-Gonzales, R.G., Carvayar-Chavez, J.A. \& Feria-Solorza, O., Electrocatalysis of Oxygen Reduction on Carbon Supported Ru-Based Catalysts in Polymer Electrolyte Fuel Cell, J. Power Source, 153, 11-17, 2006.

[3] Ralph, T.R. \& Hogarth, M.P., Platinum Met. Rev., 46(3), 117-135, 2002.

[4] Tada, T., The Current State of the Development of Electrocatalysts for Use in Fuel Cell, $1^{\text {st }}$ International Fuel Cell Expo, 2005.

[5] Mukerjee, S., Reducing Overpotensial Losses for Oxygen Reduction Reaction with Pt Based Alloys: a RRDE and in situ synchrotron XAS Investigation, Unpublish.

[6] Ross, P.N., Progress Report, Departement of Energy, Hydrogen Program USA, 2006

[7] Patel, K., Kapoor, S., Dave, D.P. \& Mukherjee, T., Synthesis of Pt, Pd, Pt/Ag, Pd/Ag Nanoparticles By Microwave Polyol Method, J. Chem.Sci., 117(4), 311-316, 2006.

[8] Oh, H.,S., Oh, J.G., Hong, Y.G. \& Kim, N., Investigation Of CarbonSupported Pt Nanocatalyst Preparation By The Polyol Process For Fuel Cell Application, Electrochemica Acta, 52(25), 7278-7285, 2007. 
[9] Hultgren, R., Raymond, L.O., Philip, D.A. \& Kenneth, K.K., Selected Value of Thermodynamic Properties of Metals and Alloys, John Wiley and Sons, 1960.

[10] Radillo-Diaz, A., Coronado, Y., Perez, L.A. \& Garzon, I.L., Structural and Electronic Properties of PtPd and PtNi Nanoalloys, Eur. Phys. J., D52, 127-130, 2009.

[11] Schmid, M., Stadler, H. \& Varga, P., Direct Observation of Surface Chemical Order by Scanning Tunneling Microscopy, Phys. Rev. Lett., 70(10), 1993.

[12] Gauthier, Y., Dolle, P., Baudoing-Savois, R., Platzgummer, E., Schmid, M. \& Varga, P., Chemical Ordering and Reconstruction of $\mathrm{Pt}_{25} \mathrm{Co}_{75}(100)$ : an LEED/STM Study, Surface Science, 396, 137-155, 1998.

[13] Pazio, A., De Francesco, M., Cemmi, A., Cardellini, F. \& Giorgi, L., Comparison of High Surface Pt/C Catalysts by Cyclic Voltametry, J. of Power Source, 105, 13-19, 2002. 